bone changes also remains uncertain, but an alternative to the enzyme induction hypothesis deserves consideration in view of the report of Ragab et $a .^{6}$ that the folate antagonist, methotrexate, can produce osteoporosis with some features similar to those produced by anticonvulsants. (Dent, personal communication). Could not the bone disease in epileptic patients also be related to the effects of anticonvulsant drugs on folate metabolism? Certainly there is a great deal of clinical overlap between the folate and metabolic bone changes in epileptic patients, as the similar correlations with urinary glucaric acid excretion would suggest, and as would be expected if both are doserelated complications.-I am, etc., Institute of Psychiatry,
London S.E.5

E. H. REYNOLDS

1 Reynolds, E. H., Mattson, R. H., and Gallagher,

B. B., Neurology (Mineap.), 1971, 21, 394. cologica et Toxicologica, 1970, 28, 265.

3 Woodbury, D. M., and Kemp, J. W., Psychiatria, Neurologia, Neurochirurgia, 1971, 74, 91.

W. Wolf, F. A., Hillen, F. C., Sprangers, and Noach, E. L., Archives Internationales A. Pharmacodynamie et de Thérapie, 1971, 194, 316. 5 Spector, R. G., British fournal of Pharmacology Ragab, A. H., Frech, R. S., and Vietti, T. J.,
Cancer, 1970, 25, 580.

\section{Research in Psychiatry}

SIR,-The question posed by your thoughtful leading article on research in psych:atry (8 April, p. 61) is of serious concern and your suggestions are most pertinent. We must look at every way of making psychiatric research more effective.

May I suggest one location for psychiatric research that is neglected but should not be overlooked: the mental hospitals. The bulk of specialist psychiatric treatment is, in Britain, still based on these institutions and their extramural extensions. May I illustrate the excellent opportunities for research which they afford from the record of the hospital in which I work. Professor Michael Shepherd's original essay in epidemiological psychiatry, ${ }^{1}$ which was based on this hospital and forecast most trends in mental hospital population of the last decade, shows to what good account administrative records can be turned. $\mathrm{He}$ has a'so pointed out the deficiency of the prime materia' for research in clinical psychopharmacology, particularly in the evaluation of new drugs which, I believe, can be met from suitable mental hospitals. At St. John's. among completed projects, we have undertaken evaluations of resernine, ${ }^{2}$ chlorpromazine, imipramine, ${ }^{4}$ the effect of recent neuroleptics on movement of patients $s^{5}$ and the psychological correlates of their act: on 6

With a modest investment in staff and equipment a considerable contribution to the pharmacology of imipramine has been completed.

Such work has been made pos-ible by the help of the Oxford Reg:onal Hospital Board, the M.R.C., a grant from the Nuffield Provinc:al Hospitals Trust, and the generosity of drug firms. The handicaps in attracting such support outside university centres are great, however, and what can be accomplished is subject to serious limitations. The chief of these is the impossibility of obtaining sustained support as opposed to support for individual projects. In this respect I believe your view that "there is no evidence that promising developments have been starved of su iport" needs qualification.-I am, etc.,

St. John's Hospital

DAVID C. WATT Shepherd, M., The Major Psychoses in an
English County, London, Chapman and Hall, 1957

2 Watt D. C., Fournal of Neurology Neurosurgery and Psychiatry 1958. 21, 297.

Neurd, M., and Watt. D. C.. foumal of 19, 232.

Elkes, A., Mode of Action of Impramine, $M$. D., Thesis, London University, 19:8. 5 Shepherd, M., Goodman N., and Watt, D. C.,

Allport, D. A., Crookes, T. G., and Watt, D. C., Neuropsychopharmacology, Amsterdam, 1964, 3, 93. Crammer, I. L., and Rolfe, B., Psychopharma-
cologia, $1970,18,26$.

\section{Private Practice}

SiR,- - How sad it was to read the letter from Mr. J. R. Kirwan, vice-president of the British Medical Students' Association (20 May, p. 464), in which he criticized the views Professor C. A. Wells (6 May, p. 346) expressed on the role of private practice in enhancing the experience and teaching training of consultants.

As a general practitioner I would endorse Professor Wells's views wholeheartedly, and would suggest that Mr. Kirwan will find when he comes to practise medicine, as he so surely will do in the near future, that those consultants who have experience of private practice have on the whole a far better and more understanding relationship with the general practitioner.

Similarly, it is rarely the private patient who wastes the doctor's time, as he is having to pay for the privilege. I wish the same could be said for a section of the population that regards the Health Service as an organization to be exploited to the ultimate for every trivial problem, whether medical or not, to the detriment of those who are really sick.

Perhaps it will surprise Mr. Kirwan to discover that there are those who do not share his views, but who are no less dedicated to the service of medicine and resent his implication that because a doctor will see private patients he must necessarily give less care to those who are not.-I am, etc.,

Eastbourne, Sussex

Michael J. EmSLIE

\section{Accidents and Fatigue in Small Boats}

SIR,-Tens of thousands of people are now taking to the sea around these islands and last year some 3,000 had to be rescued. Further, there are many unexpla ned losses of small boats, and there are deaths from such conditions as hypothermia which might be avoided by a better understanding of the problems. Anyone who has talked to yachtsmen will be struck by the frequency with which they make serious errors of judgement when fatigued, or may experience gross misinterpretation of their surroundings and even have visual hallucinations. Really too many people are involved in this activity for one to ascribe these phenomena to some peculiarity of yachtsmen. Rather one must look at the activity itself.

In sailing small boats the yachtsman is expected to perform a highly accurate task when exposed to unpleasant conditions in which he may be feeling wet, cold, seasick, and very tired. Also, he may have anxieties about the suitability of his boat or because he has his family on board, not to mention all the anxieties that beset people in ordinary life. It is not surprising, therefore, that the yachtsman is subject to special physical and mental stresses. One such example I heard of recently was that a party having crossed the Channel and being very fatigued, sailed north-west into Poole Harbour, which is flanked by low-lying land, under the impression that they were sailing up the Needles Channel which runs north-east and is flanked by white cliffs and a castle.

There are studies in progress in this department on the general question of fatigue among sailors and also into clothing and stores. I would like to ask readers for the benefit of their experience and advice on these matters under, among others, the following headings:

(1) Details of errors of any kind occurring in the course of handling small boats, and also of any odd experiences.

(2) Details of any small boat accidents at sea in which readers may have been involved professionally or even as victims.

(3) Any general observations about these problems, for example. about protective clothing, provisions, and med:cal supplies; and advice and personal experiences which could be made available to a wider public.

All details supplied would be regarded as confidential insofar as nothing that could identify an individual would be disclosed, but, of course. the intention is to provide information which will help others in the future.-I am, etc.,

Department of Mental Health,

GLIN BENNET

University of Bristol

\section{Sir Paul Chambers's Inquiry}

SIR,-Dr. A. A. Gildersleve (20 May, p. 469) questions the logic of some of the conclusions of Sir Paul Chambers in his report (Sunplement, 6 May, p. 45).

Dr. Gildersleve asks if it is logical to destroy the General Medical Services Committee and Central Committee for Hospital Medical Services if, as Sir Paul admits, they are so well informed. This question misses two central issues of criticism in the report -namely. these committees are autonomous, and not accountable to the Representative Body, and they contain non-members of the B.M.A., and are elected mainly by bodies which are not part of the B.M A.

Doubtless, Dr. Gildersleve read Section $\mathrm{X}$, para. 6 of the report, in which Sir Paul says. ". . . members of existing committees should be elected, if they are willing, to serve on the new committees. Thus it is hoped that some members of ... the C.C.H.M.S. . . . [and] ... G.M.S.C. will be willing to be nominated for election under the new system." (Supplement, 6 May, p. 64). If this occurs. then the new committees will retain the best of the old which Dr. Gildersleve thinks will be destroyed. The new committees will, in addition, be composed wholly of B.M.A. members, and answerable to the R.B. 